\title{
Inisiasi Taman D’terong sebagai Bentuk Resiliensi Komunitas Desa Panggungharjo
}

\author{
Roichan Rochmadi Irwanto ${ }^{1}$, Tuti Rokmawati ${ }^{2}$, Ratu Hanifa Pradnya Siwi ${ }^{3}$
}

\begin{abstract}
Abstrak
Pembuatan Taman D’Terong dicetuskan sebagai gagasan dari masyarakat untuk kebermanfaatan bersama. Tulisan ini memperlihatkan bentuk kepedulian sosial masyarakat melalui gerakan ini sebagai resiliensi komunitas desa terhadap COVID-19. Penelitian ini menggunakan metode penelitian kualitatif deskriptif melalui wawancara, observasi dan kepustakaan. Hasil penelitian menunjukkan bahwa konsep resiliensi komunitas terhadap bencana memiliki efek percepatan pemulihan yang baik. Dengan kerangka kerja konsep melalui pendekatan berbasis modal terbukti bahwa modal di dalamnya telah memperkuat resiliensi tersebut. Dimulai dengan inisiasi sepuluh warga yang terdampak di tengah pandemi, kemudian mengajak warga untuk berswasembada tani. Kemudian hasil panen dijual kepada warga dengan harga murah, di mana mampu meringankan beban belanja kebutuhan dan menyumbang pemasukan kas desa untuk disalurkan ke warga membutuhkan, serta pemutaran anggaran pengelolaan usaha tani.
\end{abstract}

Kata Kunci : Taman D’Terong, Resiliensi, Modal, COVID-19

\begin{abstract}
Taman D'Terong was initiated by the community for mutual benefit. This paper shows a form of community social concern as the resilience of the village community against the COVID-19. This study used descriptive qualitative methods in which the data were collected through interviews, observations, and literature review. It revealed the concept of community resilience to disasters had a good effect on recovery acceleration. Using the conceptual framework through a capitalbased approach, it is evident that capital has strengthened this resilience. It was started with the initiation of ten people who were impacted amid a pandemic, they invited others to be self-supporting in farming. Then the harvest was sold to residents at low prices so that it could lighten the burden of the basic needs and contribute to village cash income to be distributed to the community in need, as well as the supporting budget management of the agricultural business.
\end{abstract}

Keywords: Taman D’Terong, Resilience, Capital, COVID-19

\section{Pendahuluan}

Saat ini dunia tengah dikejutkan dengan mewabahnya suatu penyakit baru yakni COVID-19 (Coronavirus Diseases-19) atau dikenal sebagai SARS-CoV-2. COVID-19 ini sendiri merupakan jenis virus baru yang belum teridentifikasi sebelumnya pada manusia. Kementerian Kesehatan RI (2020) menyebutkan bahwa tanda dan gejala yang dapat dilihat pada orang yang terinfeksi virus COVID-19 seperti batuk, demam, dan sesak nafas. Virus yang disinyalir mulai mewabah pada tanggal 31 Desember 2019 di Kota Wuhan, Provinsi Hubei, China ini telah menyebar begitu cepat ke negara lain hanya dalam beberapa bulan saja. Kemudian di tanggal 30 Januari 2020 yang lalu World Health Organization (WHO) menetapkan kejadian tersebut sebagai Kedaruratan Kesehatan Masyarakat yang Meresahkan Dunia (KKMMD) atau Public Health Emergency of International Concern (PHEIC) dan tepat pada tanggal 11 Maret 2020 WHO resmi menetapkan COVID-19 sebagai pandemi. Indonesia tak luput menjadi salah satu dari sekian banyak negara terdampak COVID-19. Menurut Laporan Gugus Tugas Percepatan Penanganan COVID-19 (2020) bahwa per 05 September 2020 ada 190.665 pasien terindikasi positif di Indonesia.

Hampir sama dengan kebijakan yang diambil oleh negara-negara lain, Pemerintah

\footnotetext{
${ }^{1}$ Departemen Pembangunan Sosial dan Kesejahteraan, Universitas Gadjah Mada (email korespondensi: fukuroworld@mail.ugm.ac.id)

${ }^{2}$ Departemen Pembangunan Sosial dan Kesejahteraan, Universitas Gadjah Mada (email : tutirokmawati@mail.ugm.ac.id)

${ }^{3}$ Departemen Pembangunan Sosial dan Kesejahteraan, Universitas Gadjah Mada (email : ratuhanifa@mail.ugm.ac.id)
} 
Indonesia mengambil langkah pembatasan pergerakan masyarakat dalam berkegiatan. Kebijakan ini diatur dalam Peraturan Menteri Kesehatan (Permenkes) Nomor 9 Tahun 2020 mengenai Pedoman Pembatasan Sosial Berskala Besar (PSBB). Kebijakan yang dicanangkan ini diharapkan mampu untuk mengurangi mobilitas penduduk agar laju penularan tidak semakin menjamur. Akan tetapi, kebijakan tersebut membuat banyak kegiatan ekonomi terhenti untuk sementara waktu akibat banyaknya tenaga kerja yang terpaksa berhenti untuk bekerja yang berimplikasi pada turunnya daya beli hingga menimbulkan kelesuan ekonomi. Hal ini menimbulkan berbagai masalah baru antara lain kemiskinan yang semakin meningkat, UMKM banyak yang gulung tikar, serta sektor industri mengalami kerugian besar akibat bahan baku produksi kian menipis sehingga berimplikasi pada hasil produksi dan terjadilah peristiwa gelombang pemutusan hubungan kerja (Indayani \& Hartono, 2020).

Fenomena tersebut dapat menyebabkan roda perekonomian Indonesia tumbuh lambat dari sebelumnya dan diprediksi Indonesia akan memasuki resesi pada tahun 2020 ini. Resesi merupakan kondisi sebuah negara yang ekonominya mengalami kontraksi pertumbuhan selama dua kuartal berturut-turut (Arieza, 2020). Tercatat bahwa pada kuartal I tumbuh negatif di bawah $5 \%$, pada kuartal II tumbuh negatif 5,32\%, dan diprediksi pada kuartal III ekonomi Indonesia akan tumbuh negatif 2,9\% hingga 1\% (Moko, 2020). Menurut Direktur Institute for Development of Economics and Finance (INDEF) Enny Sri Hartati, dampak dari resesi yang secara riil dirasakan oleh masyarakat adalah sulitnya mendapat lapangan pekerjaan, diikuti oleh jatuhnya daya beli masyarakat karena berkurangnya pendapatan masyarakat. Jika resesi terus berlanjut, diperkirakan Indonesia akan membutuhkan waktu lebih dari lima tahun untuk kembali tumbuh positif (Yuniar, 2020).

Dampak yang ditimbulkan dari resesi ekonomi mendorong masyarakat untuk meningkatkan resiliensi sebagai upaya bertahan di masa pandemi. Resiliensi merupakan kemampuan atau kapasitas sebuah komunitas yang memiliki potensi terpapar bencana untuk beradaptasi secara positif dan efektif sehingga mampu mencapai dan mempertahankan suatu tingkat fungsi dan struktur yang dapat diterima (Wahyudi, Ritohardoyo, \& Pitoyo,
2020). Salah satu bentuk resiliensi yang cukup penting ialah pada usaha perwujudan resiliensi kemandirian pangan. Pada praktiknya usaha kemandirian pangan ini sering dilakukan dalam bentuk menanam sayuran, tanaman obat keluarga, dan peternakan yang memanfaatkan lahan yang kosong. Hal ini dilakukan untuk memenuhi ketersediaan pangan lokal dan usaha pemberdayaan masyarakat. Desa Panggungharjo merupakan salah satu desa di Kabupaten Bantul yang menerapkan usaha mandiri pangan dengan menanam sayuran dan beternak. Bentuk usaha yang diterapkan oleh Desa Panggungharjo kemudian berkembang menjadi usaha pertanian yang mampu meringankan pemenuhan pangan masyarakat sekitar. Selain itu Taman D'Terong memberi peluang kerja bagi kelompok masyarakat yang mengalami dampak pandemi.

Dari beberapa hal yang disampaikan di atas maka tulisan ini membahas mengenai terciptanya Taman D'terong sebagai bentuk resiliensi komunitas Desa Panggungharjo dalam mengatasi pengangguran dan kebutuhan pangan desa di tengah Pandemi COVID-19. Taman D'terong menjadi fokus dalam penelitian ini karena taman tersebut sebagai wujud nyata inisiatif warga desa Panggungharjo dalam mencapai kemandirian pangan di masa pandemi. Tulisan ini bertujuan mengetahui seberapa jauh resiliensi komunitas desa ini sudah mempercepat pemulihan warga desa dari dampak pandemi COVID-19. Pembahasan tulisan ini kemudian dapat mampu menjadi rekomendasi bagi pengembangan penelitian, serta menjadi masukan bagi pengembangan pembuatan kebijakan darurat sebagai respons dampak pandemi COVID-19.

\section{Kerangka Teori}

Istilah ketahanan sering kali digunakan dengan cara yang sama sebagaimana pengertian dari "memantul kembali" yang dicerminkan dalam istilah "resiliere" dari bahasa Latin yang berarti "melompat kembali" (Mayunga, 2007). Timmerman (1981) mendefinisikan istilah ketahanan sebagai ukuran dari suatu sistem atau bagian dari kapasitas sistem itu untuk menyerap dan pulih dari peristiwa berbahaya. Mengikuti karyanya banyak definisi lain dari konsep ketahanan telah muncul di bidang studi bahaya dan bencana. Namun, terlepas dari semua hal tersebut ternyata belum ada konsensus di antara 
peneliti maupun praktisi mengenai definisi umum untuk konsep ini. Mayunga (2007) menyatakan bahwa:

"For instance, most authors use the term capacity/ability to define the concept of disaster resilience and confine the concept to people, a group of people, a community, or a society. This generally means that, there is an agreement among researchers that the notion of disaster resilience should be associated with the capacity/ability of people, a group of people, a community or a society to cope with disasters. Worth noting also is the wide usage of the term recovery in the definitions. Most authors define the concept of disaster resilience in terms of the speed or how quickly people, a group of people, a community or a society can recover from the disaster impacts".

Tulisan ini mencoba mengacu konsep ketahanan bencana masyarakat sebagai kapasitas atau kemampuan masyarakat untuk mengantisipasi, mempersiapkan, merespon, dan pulih dengan cepat dari dampak bencana. Sehingga, bukan hanya seberapa cepat masyarakat bisa pulih dari dampak, tetapi juga kemampuan untuk belajar, mengatasi, atau beradaptasi dengan bahaya. Oleh karena itu, ketahanan komunitas harus diorganisir sedemikian rupa sehingga efek bencana minimal dan proses pemulihan cepat.

Mayunga (2007) di dalam karya tulisnya mengusulkan pendekatan berbasis modal sebagai kerangka kerja dalam menilai ketahanan masyarakat terhadap bencana. Tierney (2006) dalam Manyunga (2007) di karya tulisnya mencoba memperluas pendekatan berbasis modal dengan memasukkan lima bentuk utama modal, yakni: sosial, ekonomi, fisik, manusia, dan alam. Dalam menilai ketahanan komunitas dilakukan dengan proses yang kompleks karena interaksi yang dinamis dengan orang, komunitas, masyarakat, dan lingkungan. Saat ini ada banyak kerangka kerja konseptual untuk mengukur konsep. Secara umum kerangka kerja ini mengonseptualisasikan ketahanan bencana dengan cara yang serupa, di mana mereka berfokus pada faktor-faktor serupa apa saja yang dapat mengurangi kerentanan dan meningkatkan ketahanan. Faktor-faktor tersebut meliputi sumber daya ekonomi, aset dan keterampilan, informasi dan pengetahuan, dukungan dan jaringan yang mendukung, akses ke layanan, dan nilai-nilai komunitas bersama.

Melalui kerangka berpikir atas pemaknaan resiliensi komunitas terhadap bencana dengan pendekatan modal akan relevan dengan pembahasan yang coba diangkat dalam penelitian ini. Tulisan ini mencoba untuk melihat fenomena masyarakat di Desa Panggungharjo, Kecamatan Sewon, Kabupaten Bantul, Daerah Istimewa Yogyakarta. Di desa tersebut banyak warga desa yang mengaku telah ter-PHK dan menganggur akibat dari adanya bencana Kejadian Luar Biasa (KLB) pandemi COVID-19 saat ini. Kemudian mereka berinovasi, beradaptasi dan bertahan dari semua hal ini dengan membuat kebun desa yang nantinya menjadi sumber penghasilan mereka serta menjadi penambah pemenuhan kemandirian pangan desa terhadap bencana KLB pandemi COVID-19. Melalui konsep ketahanan pangan, suatu negara dikatakan baik apabila diukur dari tingkat ketersediaan pangan rumah tangga, walaupun kebutuhan pangan tersebut harus dipenuhi dengan cara membeli produk impor. Hal ini memperlihatkan bahwa bagi negara, kecukupan dan ketersediaan pangan yang menjamin bahwa setiap penduduk atau individu akan mampu hidup sehat dan aktif saja harusnya tidaklah cukup. Oleh karena itu penting adanya kesadaran berbagai aktor untuk mewujudkan keberhasilan ketahanan pangan tersebut, salah satunya dapat dimulai dengan aktor terkecil, yakni komunitas desa dengan merealisasikan ketahanan pangan desa melalui usaha pemenuhan pangan secara mandiri yang nantinya dapat dikonsumsi bersama.

Dengan pendekatan modal yakni modal sosial, ekonomi, fisik, sumber daya manusia dan alam terlihat dalam kegiatan yang telah mereka usahakan, dimulai dengan adanya bantuan bibit sayuran dari pemerintahan desa, pembiayaan bersama (jimpitan), pemanfaatan lahan warga, kemudahan akses jalan dan jembatan ke taman, keikutsertaan warga dalam mengurus taman, kemudian kemampuan mengantarkan masyarakat untuk bergerak membangun kebun bersama sebagai upaya ketahanan pangan desa di tengah krisis global yang ikut melanda Indonesia ini. Bentuk modal sosial yang mengakar pada masyarakat desa terwujud dalam bentuk, seperti: kepercayaan (trust), saling pengertian (mutual understanding), dan nilai-nilai bersama (shared value) (Cahyono \& Ardian, 2012). Modal 
sosial terletak pada kemampuan masyarakat dalam melakukan kerja sama untuk membangun suatu relasi yang memiliki hubungan timbal balik dan saling menguntungkan yang dibangun atas dasar kepercayaan dan sekaligus ditopang oleh norma sosial yang ada (Cahyono \& Ardian, 2012).

Melalui kajian literatur yang dibangun, tulisan ini berusaha menyajikan bentuk kepercayaan timbul di dalam masyarakat. Selain itu juga dilihat terkait adanya sikap saling mengerti atas kondisi satu sama lain, apabila ada yang terkendala ekonomi atau kebutuhan lainnya segera dapat dibantu melalui kegiatan ini, bahkan telah ada yang bersedia menyerahkan lahan pekarangannya untuk digunakan bersama. Serta ditambahkan dengan adanya nilai-nilai bersama yang dianut di dalamnya yakni nilai kekeluargaan. Kedua, modal ekonomi yang terlihat dari investasi warga dalam ikut menyumbang dana jimpitan untuk pengelolaan taman dan pembelian benih sayur. Perekonomian yang tumbuh lebih stabil umumnya akan meningkatkan ketahanan, sedangkan yang tidak akan menjadi indikator meningkatnya kerentanan (Buckle dalam Mayunga, 2007). Ketiga, modal fisik yang terlihat dari mudahnya akses jalan ke arah taman, bahkan taman D'Terong menghadap langsung ke jalan desa. Modal fisik merupakan salah satu sumber daya penting dalam membangun kapasitas masyarakat dalam menghadapi bencana. Keempat, modal sumber daya manusia terlihat dari keikutsertaan warga untuk bersama sama mengelola dan mengurus tanaman serta sarana lain di taman. Modal sumber daya manusia terwujud dalam penduduk usia kerja yang memungkinkannya bekerja secara produktif dengan bentuk-bentuk lain modal untuk menopang produksi ekonomi (Smith dkk dalam Mayunga, 2007). Terakhir, modal alam yang terwujud, seperti: air, tanah, ekosistem yang sehat, udara, dan iklim yang mendukung swasembada tani ini.

Inovasi masyarakat desa untuk memanfaatkan lahan pekarangan salah satu warga untuk diusulkan dan dimanfaatkan bersama agar memberikan kebermanfaatan bagi seluruh desa, gerakan ini dimulai dari lingkup RT dan sedang diusulkan ke tingkat kelurahan agar menjadi kegiatan pertanian yang berkelanjutan (sustainable). Beberapa dari masyarakat yang tidak memiliki pekerjaan tetap ikut diberdayakan dan memiliki andil yang besar dalam kegiatan ini. Nantinya hasil panen dari kebun tersebut sebagian akan dibagikan ke masyarakat yang membutuhkan dan sebagian di jual untuk perputaran modal kas perawatan kebun. Hubungan serta potensi modal seperti ini yang membuat lingkup masyarakat desa menjadi resiliensi terhadap dampak pandemi COVID-19 saat ini.

\section{Metode Penelitian}

Penelitian ini merupakan penelitian kualitatif. Menurut Moleong (2005:6), penelitian kualitatif adalah penelitian yang bermaksud untuk memahami fenomena tentang apa yang dialami oleh subjek penelitian misalnya motivasi, persepsi, perilaku secara holistik yang dijelaskan dengan deskripsi dalam bentuk katakata dan bahasa pada suatu konteks khusus yang alamiah dan dengan memanfaatkan berbagai metode alamiah. Metode kualitatif deskriptif menyesuaikan pendapat antara peneliti dengan informan. Pemilihan metode ini dilakukan karena analisisnya tidak bisa dalam bentuk angka dan penelitian ini lebih mendeskripsikan segala fenomena yang ada di masyarakat secara jelas. Lokasi penelitian ditetapkan berdasarkan desa yang terdapat gerakan adaptasi masyarakat di tengah pandemi dengan mengoptimalkan modal sosial yakni di Desa Panggungharjo, Kecamatan Sewon, Kabupaten Bantul, dengan jangka waktu penelitian adalah 3 minggu yaitu dimulai pada 17 September hingga 08 Oktober 2020.

Teknik pengumpulan datanya melalui observasi dan wawancara. Wawancara dilakukan terhadap 15 narasumber yang terdiri dari 1 orang kepala dukuh, 5 orang kelompok swadaya tani nekat maju, dan 9 warga yang ikut serta dalam kegiatan bercocok tanam di Desa Panggungharjo. Wawancara dilakukan dalam bentuk diskusi dan percakapan dua arah dengan menyusun daftar pertanyaan untuk memudahkan dalam memperoleh informasi mengenai awal mula munculnya kegiatan, keterlibatan sektor pemerintah, dan dinamika masyarakat yang terlibat dalam kegiatan bercocok tanam di Desa Panggungharjo. Sumber data terdiri atas sumber primer dan sekunder. Sumber primer didapat melalui wawancara dan observasi, sedangkan sumber sekunder didapat melalui studi kepustakaan dengan bantuan media cetak, internet dan catatan lapangan. Adapun 
model analisis yang digunakan dalam penelitian ini adalah metode analisis deskriptif kualitatif, yaitu metode penelitian yang memanfaatkan data kualitatif dan dijabarkan secara deskriptif. Penelitian secara deskriptif ini dimaksudkan untuk mendeskripsikan data penelitian sesuai dengan variabel-variabel yang diteliti. Dalam model analisis data terdiri atas tiga komponen yaitu reduksi data, penyajian data dan penarikan kesimpulan.

\section{Hasil \\ Kondisi Desa Panggungharjo di Tengah Pandemi COVID-19}

Desa Panggungharjo terletak di Kecamatan Sewon, Kabupaten Bantul, Provinsi Daerah Istimewa Yogyakarta. Berdasarkan kondisi geografis wilayah Desa Panggungharjo merupakan salah satu desa di Kabupaten Bantul yang secara langsung berbatasan dengan Kota Yogyakarta. Lebih lengkap batas-batas Desa Panggungharjo adalah sebelah utara berbatasan dengan Kota Yogyakarta, sebelah timur berbatasan dengan Desa Bangunharjo, sebelah selatan berbatasan dengan Desa Timbulharjo, sebelah barat berbatasan dengan Desa Pendowoharjo dan Desa Tirtonirmolo, Kecamatan Kasihan.

Persebaran COVID-19 negara-negara di dunia tak terkecuali Indonesia salah satunya, telah membuat respon cepat atas penyebaran pandemi ini yang masih beberapa kali mengalami kenaikan. Menurut survei yang dilaksanakan snapcart pada tanggal 17-28 Mei 2020 terhadap 2000 responden yang terdiri dari laki-laki dan perempuan berusia 15-50 tahun menyatakan bahwa terdapat 48 persen responden yang mengaku kehidupan sosialnya terganggu. Kentalnya kehidupan bersosialisasi dan gotong royong membuat mereka mencari jalan untuk tetap berinteraksi meskipun adanya physical distancing (Dianawanti 2020). Kebijakan menutup beberapa daerah, membatasi interaksi satu sama lain, dan kebijakan lain seputar protokol kesehatan berdampak pada 267 juta orang di Indonesia (BPS 2018). Kemudian terdapat beberapa negara yang menerapkan kebijakan serupa, seperti Spanyol, Tiongkok, Afrika, Polandia, Denmark dan lain sebagainya (Ruth 2020).

Tak terkecuali beberapa warga di Desa Panggungharjo yang menceritakan tentang dirinya atau bahkan tetangganya yang harus kehilangan pekerjaan dan menganggur di tengah pandemi saat ini. Pembatasan berskala yang diterapkan oleh pemerintah menghambat kegiatan perekonomian serta pemenuhan kebutuhan hidup mereka. Selain itu keadaan krisis kesehatan global seperti ini sangatlah penting untuk menjaga kualitas bahan masakan untuk konsumsi keluarga dan diri sendiri, maka dari itu alangkah lebih baik apabila bahan untuk lauk makanan merupakan produksi lokal karena diharapkan akan mengurangi kontaminasi dengan virus COVID-19 di saat peralihan dari produsen, distributor, kemudian ke konsumen. Selain itu inflasi harga bahan-bahan untuk memasak juga tidak dapat dihindari, sehingga banyak warga yang merupakan keluarga menengah ke bawah cukup kesulitan apabila harus menyesuaikan harga baru bahan dasar makanan di pasaran. Kemudian banyak dijumpai beberapa penutupan pusat perbelanjaan oleh pemerintah dikarenakan terbukti menyebarkan penularan virus COVID-19. Apabila hal-hal seperti ini terus berlanjut, dapat dipastikan banyak keluarga yang tergolong rentan tidak mampu menjalankan kehidupannya sebagaimana mestinya. Golongan rentan (vulnerable people) atau yang tidak beruntung (disadvantage people) seperti inilah yang perlu segera beradaptasi, bangkit untuk menyambung kehidupannya. Maka dari itu, beberapa masyarakat Desa Panggungharjo berinovasi untuk berswasembada tani dengan memanfaatkan potensi yang telah ada di desa

\section{Inisiasi Taman D'Terong Desa Panggungharjo}

Inovasi pemanfaatan lahan kosong untuk kegiatan produktif dilakukan untuk menciptakan kemandirian pangan, mengatasi permasalahan pengangguran, sekaligus dapat dijadikan tempat rekreasi bagi warga desa yang jenuh akan pembatasan berskala seperti saat ini. Ketika di lokasi penelitian beberapa warga desa telah ditanya mengenai bagaimana awal taman tersebut dapat terbentuk, secara umum mereka menjelaskan bahwa hal tersebut berawal dari keinginan Pemerintah Daerah Bantul untuk menjadikan desa wisata berskala lokal dengan objek wisata sayuran. Sebagai bentuk realisasinya Pemerintah daerah telah memberikan stimulus melalui pengadaan bantuan benih sebelum pandemi. Akan tetapi, hal tersebut terhenti karena pemerintah daerah beralih fokus ke permasalahan penanganan 
COVID-19. Dari adanya benih yang tidak terurus tersebut muncul gagasan dari salah satu warga Dongkelan, RT 08 Desa Panggungharjo untuk merawat dengan menggandeng beberapa swadaya tani di daerahnya. Gerakan swadaya ini juga kemudian dilakukan untuk mendukung permasalahan pandemi COVID-19 yang menimbulkan dampak ekonomi secara luas.

Salah satu informan yang bernama Babe yang merupakan salah seorang tokoh inisiator di Desa Panggungharjo memiliki keinginan untuk merawat tanaman dan menjaga kemandirian pangan masyarakat setempat. Babe berusaha meyakinan warga sekitar untuk berupaya memanfaatkan lahan kosong, sebagai tempat untuk menanam sayuran. Setelah meminta izin penggunaan lahan masyarakat, terdapat 10 warga yang secara sukarela ikut serta dalam pengelolaan lahan tersebut dengan sekaligus memberdayakan warga yang menganggur oleh karena dampak pandemi COVID-19. Selama kegiatan berlangsung mereka secara sukarela menggunakan uang pribadi sebagai dana awal operasional. Hal tersebut dikarenakan belum ada bantuan mengenai pendanaan dari pihak lain seperti pemerintah desa maupun daerah. Persetujuan beberapa orangyang turut serta dalam pengelolaan Taman D`terong ini merupakan buruh lepas yang pekerjaannya berkurang selama pandemi dan beberapa ada yang menjadi korban PHK. Oleh karenanya, masyarakat setuju dan bersedia untukikut menjadi bagian dari penanaman dan perawatan di Taman D`terong.

Komoditas pangan yang ditanam di taman tersebut meliputi terong, cabai, kubis, dan lain sebagainya, bahkan tempat tersebut pula dijadikan tempat budidaya ikan lele. Kegiatan tersebut dilaksanakan sejak pandemi berlangsung dan berdasar penjelasan Babe selaku koordinator lapangan sekaligus yang hampir setiap hari ke lokasi, kegiatan itu sekali lagi juga dilakukan karena melihat banyaknya warga yang menganggur baik karena tidak memiliki pekerjaan akibat PHK atau libur sekolah. Setelah empat bulan berlalu dan sudah sebelas kali panen yang didapat, namun keberhasilan panen mayoritas hanya merupakan komoditas terong, sebab tanaman lain ternyata tidak dapat tumbuh maksimal dikarenakan kurangnya pengetahuan mereka mengenai teknik menanam sayuran. Meskipun demikian, dulunya banyak warga disini yang menggantungkan hidupnya pada sektor pertanian dan pada akhirnya beralih profesi, kemudian lahan pertanian di sana telah berubah menjadi lingkungan perumahan yang padat. Hasil panen dari taman d'terong tersebut dijual kepada warga sekitar dengan harga yang sangat murah yang nantinya hasil penjualan tersebut akan digunakan sebagai dana operasional pengelolaan taman. Penjualan selama ini mendapatkan uang sekitar Rp 800.000,00, namun Babe menerangkan bahwa dana sebesar Rp 400.000,00 telah digunakan untuk renovasi taman agar terlihat lebih menarik, seperti digunakan dalam pembiayaan membangun tempat duduk dari bambu, kolam untuk ikan lele, jembatan, serta lampu penerangan.

Berbagai hambatan sempat dijelaskan oleh Babe, yakni kurangnya dana untuk mengelola taman tersebut dikarenakan selama ini mereka swadaya, kurangnya pengetahuan akan teknik menanam yang benar di beberapa tanaman sehingga membuat proses penanaman, perawatan, hingga panen tidak menuai hasil yang maksimal. Babe dan rekannya yang disebut sebagai "petani nekat maju" berinisiatif untuk mengubah dan membuktikan kepada pemerintah daerah bahwa dari Desa Panggungharjo tersebut mampu melakukan hal yang inovatif serta layak untuk mendapatkan dukungan baik berupa dana maupun pelatihan agar menjadi gerakan pertanian yang berkelanjutan meskipun nantinya pembatasan berskala dihapuskan dan Pandemi COVID-19 telah dinyatakan tidak ada kasus penularan kembali.

\section{Diskusi}

Konsep ketahanan bencana masyarakat sebagai kapasitas atau kemampuan masyarakat untuk mengantisipasi, mempersiapkan, merespon, dan pulih dengan cepat dari dampak bencana. Mayunga (2007) mencoba mengusulkan pendekatan modal sebagai kerangka kerja dalam menilai ketahanan suatu masyarakat terhadap bencana. Sehingga pendekatan berbasis modal tersebut memiliki beberapa komponen yang diperlukan agar perekonomian masyarakat dapat berlanjut. Bagan dibawah menggambarkan mengenai pendekatan modal yang erat kaitannya dengan resiliensi komunitas terhadap bencana.

\section{Modal Sosial}

Di dalam hal kehidupan bermasyarakat untuk mengukur resiliensi komunitas melalui kepemilikan modal sosial akan terlihat melalui 
Roichan Rochmadi Irwanto, Tuti Rokmawati, Ratu Hanifa Pradnya Siwi - Inisiasi Taman D'terong sebagai Bentuk Resiliensi Komunitas Desa Panggungharjo

Gambar 1

Konsep Kerangka Kerja Hubungan Antara Modal Dan Resiliensi Komunitas Terhadap Bencana

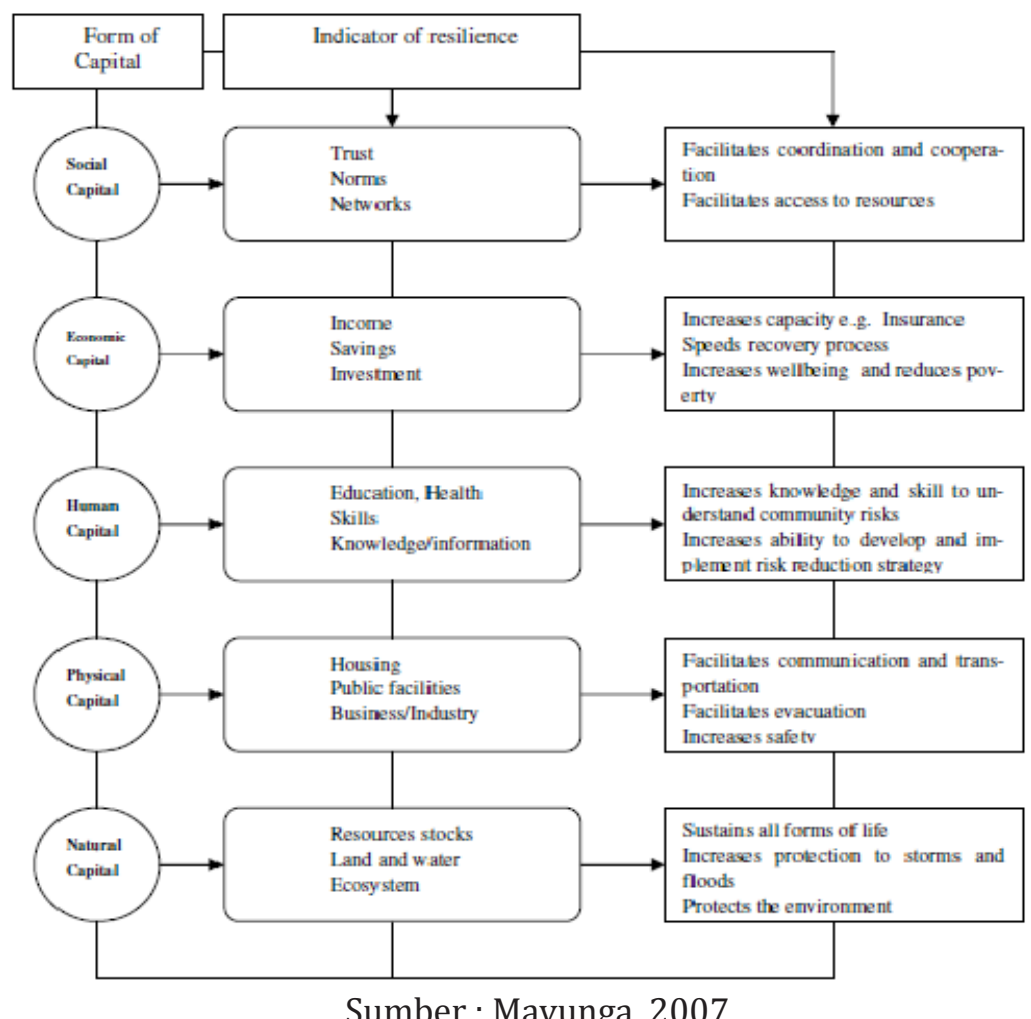

kepercayaan, nilai-nilai, dan hubungan atau jaringan relasi. Pandangan dari kepemilikan ketiga hal tersebut setara terwujud yaitu dalam perilaku atau pun anggapan bahwa tidak ada yang akan mencuri (gak bakal ana sing nyolong), nilai-nilai untuk saling membantu satu sama lain (ngewangi sing susah), dan hubungan yang baik dalam bertetangga (nangga).

"Disini itu kita yakin gak bakal ana niat nyolong (tidak ada niat mencuri) sayuran atau bibit lele di sini, karena satu sama lain nangga (bertetangga) sudah ada hubungan baik satu sama lain. Kemudian taman ini didasarkan atas kesukaan saya menanam tanaman, membantu kebutuhan pangan desa, dan bantu tetangga yang nganggur, ngewangi sing susah (membantu yang susah)." (Babe, Wawancara 17 September 2020).

Ketiga kriteria anggapan tersebut memperlihatkan adanya modal sosial yang telah melekat di diri dan komunitas Desa Panggungharjo. Dalam budaya Jawa yang masih dengan baik memegang budaya warisan, keramah tamahan dalam bertetangga, merasakan senasib sepenanggungan, kepercayaan satu sama lain dalam menjaga kebun atau sawah atau ternak yang dimiliki di saat bekerja, dekat mengenal satu sama lain, dan hal-hal lainnya masih dimiliki dan diturunkan kepada anak cucunya secara turun temurun.

Menurut Sudirah, S., et al., (2020) bahwa modal sosial memiliki kontribusi terhadap resiliensi komunitas terhadap bencana yang sedang dihadapi, seperti COVID-19 saat ini. Resiliensi komunitas terhadap COVID-19 melalui pembuatan taman tersebut mampu membantu individu yang terdampak melalui kegiatan pengelolaan taman yang bahkan bisa menuai hasil panen berkali-kali. Resiliensi dengan modal ini mampu meningkatkan produktivitas pangan masyarakat melalui diversifikasi pertanian. Usaha-usaha diversifikasi pertanian tersebut meliputi penanaman palawija, pertambakan kolam ikan lele, dan bahkan menjadi sarana rekreasi melepas kejenuhan masyarakat akibat kebijakan pembatasan yang ada. 


\section{Modal ekonomi}

Di dalam membangun resiliensi komunitas desa terhadap Pandemi COVID-19 perlu adanya dukungan atas kepemilikan modal, salah satunya adalah kepemilikan modal ekonomi yang dapat dilihat dari pendapatan, tabungan, serta investasi. Dalam hasil temuan penelitian ini semua informan pengelola mengatakan bahwa penganggaran untuk gerakan pengelolaan Taman D'Terong ini berasal dari dana pribadi setiap warga yang menjadi inisiator yang kemudian hasil dari panen taman d'terong tersebut dijual kepada warga sekitar dengan harga yang sangat murah yang nantinya hasil penjualan tersebut akan digunakan sebagai dana operasional pengelolaan taman. Penjualan selama ini mendapatkan uang sekitar Rp $800.000,00$, namun Babe menerangkan bahwa dana sebesar Rp 400.000,00 telah digunakan untuk renovasi taman agar terlihat lebih menarik, seperti: membangun tempat duduk dari bambu, kolam untuk ikan lele, jembatan, serta lampu penerangan. Kemudian di sini beberapa warga yang pengangguran karena kehilangan pekerjaannya di tengah Pandemi saat ini ikut diberdayakan dan akan mendapat kebermanfaatan berupa pendapatan uang ataupun bagi hasil panen.

"Tapi hambatannya di sini mbak memang sebenarnya dana masih kurang untuk mengelola taman tersebut dikarenakan selama ini kita hanya swadaya, ya saya sih berharapnya kita digandeng sama pemerintah, dibantu lah intinya, biar kegiatannya tetep jalan". (Babe, Wawancara 17 September 2020).

Melihat respon dari informan Babe tersebut telah menunjukkan bahwa telah ada anggaran dana yang dijadikan tabungan serta investasi yakni dari hasil penjualan produk tani Taman D'Terong yang terus diputar kembali dalam perbaikan-perbaikan sarana prasarana pendukung, dan kemudian hasil dari penjualan juga beberapa persen untuk dibagikan bagi warga yang ikut mengelola bersama, dapat dikatakan sebagai pendapatan tambahan atau utama warga.

\section{Modal Sumber Daya Manusia}

Modal Sumber Daya Manusia diukur melalui tingkat edukasi, kesehatan, skill atau kemampuan, pengetahuan atau informasi. Menurut data yang diperoleh dari kepala dukuh setempat, Bapak Edy Sarwono mengatakan bahwa jumlah penduduk RT.08 Dongkelan Panggungharjo ada 61 kepala keluarga, 14 janda, dan 25 pengusaha (Data Survei 2019). Hal tersebut membuktikan banyak sumber daya manusia yang dapat dimanfaatkan. Selain itu jika meninjau dari hasil temuan dari informan terlihat bahwa mereka memiliki pengalaman akan kegiatan bertani karena sebelumnya juga pernah berprofesi sebagai petani di saat lahan di desa tersebut belum dialih fungsikan sebagai mayoritas lahan perumahan, namun kendati demikian warga desa di sana merasa tetap memerlukan pelatihan dalam kegiatan bertani karena tidak semua bibit yang ada ternyata dapat menuai keberhasilan.

"Di sini juga banyak yang kerja jadi petani dulu mbak, tapi sudah pindah profesi". (Bapak Jono, Wawancara 17 September 2020).

"Kita itu bisa bertani mbak tapi tidak semua bibit yang ada di sini kami paham betul bagaimana cara perawatannya, karena tidak semuanya kami tanam tanaman ini dulu pas jadi petani". (Bawono, Wawancara 17 September 2020).

Oleh karena itu dapat disimpulkan bahwa para warga di sana telah dibekali dengan pengetahuan terkait cara bertani di beberapa jenis tanaman dan dari hasil observasi penelitian mereka terlihat mampu beraktivitas berat dalam bertani di Taman D'Terong. Beberapa informan juga mengatakan bahwa di luar pengetahuan bertani yang telah mereka miliki, para petani nekat maju ini juga menanyakan informasi seputar dunia pertanian yang tidak mereka pahami kepada sahabat atau pun anggota keluarganya yang melek teknologi.

\section{Modal Fisik}

Dalam melihat modal fisik di dalam resiliensi komunitas terhadap bencana juga menjadi faktor kepemilikan yang terpenting. Di mana dengan adanya kemudahan akses di dalam perumahan, fasilitas publik, bahkan bisnis perusahaan atau industri. Dari hasil observasi peneliti serta beberapa pendapat dari informan terlihat bahwa kawasan Taman D'Terong ini mudah untuk diakses warga desa karena letaknya yang dekat dengan perumahan sehingga seringkali 
Roichan Rochmadi Irwanto, Tuti Rokmawati, Ratu Hanifa Pradnya Siwi - Inisiasi Taman D'terong sebagai Bentuk Resiliensi Komunitas Desa Panggungharjo

dijadikan tempat berdiskusi, bertukar kabar, dan berkumpul warga di desa tersebut.

"Senenglah bisa buat refreshing, liat ijo ijo kan jadine ayem apalagi deket rumah saya ini jadi ikutan suka taneman malahan". (Pak Sobirin, Wawancara 18 September 2020).

"Seneng banget kok mbak apalagi nek sore rame anak-anak, bapak-bapak, ibu-ibu, jadi bisa ngobrol-ngobrol. Terus ini enak juga ada tempat buat duduk-duduk, tiap bosen saya kesini sekalian srawung". (Bu Sari, Wawancara 18 September 2020).

Dari hal tersebut dapat dikatakan telah ada kepemilikan akan modal fisik di desa ini yang menyertai gerakan pengelolaan Taman D'Terong. Jalan desa tersedia, jalan serta jembatan menuju taman tersedia, dekat dengan kawasan perumahan dan fasilitas publik seperti kran air sebagai sumber pengairan Taman D’Terong.

\section{Modal Alam}

Selain modal-modal di atas kepemilikan atas modal alam juga tidak kalah penting. Modal alam terdiri atas kepemilikan persediaan sumber daya atas tanah, air, dan sumber daya alam lainnya. Modal alam merupakan potensi yang tidak semua daerah memilikinya, maka dari itu kepemilikan atas modal ini cenderung khas dan terbatas.

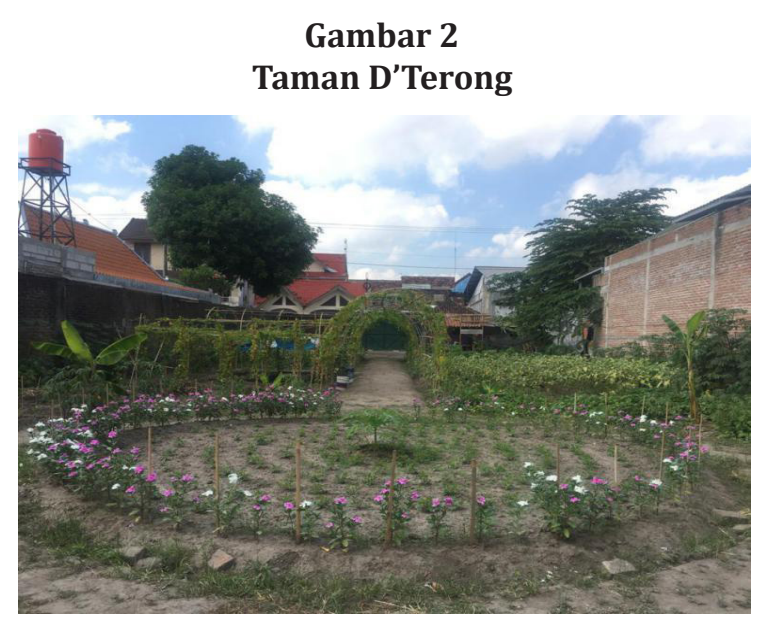

Sumber : Dokumentasi Pribadi, 2020

"Dulu untuk buat taman ini kita nembusin lahan milik warga untuk diolah daripada tidak dipakai untuk apapun, selain itu juga dekat dengan saluran air jadi mudah untuk penyiramannya nanti". (Catur dan Yono, Wawancara 19 September 2020)

Modal alam di Desa Panggungharjo dapat dikatakan menjadi pelengkap atas modalmodal yang harus terpenuhi apabila berusaha mengadakan resiliensi komunitas desa terhadap Pandemi COVID-19. Melalui kepemilikan atas modal-modal utama tadi akan mempercepat arah pemulihan dari resiliensi komunitas yang sedang diusahakan dalam gerakan kepedulian sosial atas keadaan satu sama lain dan ingin mencapai pemulihan serta kebermanfaatan bersama.

Dampak yang dirasakan dalam usaha resiliensi komunitas sebagaimana yang terlihat di gerakan pengelolaan Taman D'Terong antara lain adalah berperan dalam membantu percepatan pemulihan keadaan warga Desa Panggungharjo dari segi ekonomi, sosial, maupun lingkungan. Hal tersebut terwujud dengan adanya gerakan ini mampu membuka lapangan pekerjaan baru, memberikan solusi atas pemenuhan kebutuhan pangan desa yang higienis dan terjangkau sebagai realisasi kemandirian pangan desa , memberikan pengalaman berwirausaha yakni pertanian, mengembangkan hubungan keakraban satu sama lain, mengisi waktu luang, menyalurkan hobi, bahkan menjadi sarana rekreasi yang mampu menghilangkan kejenuhan akibat pembatasan berkala yang ditetapkan oleh pemerintah di tengah situasi krisis global saat ini. Dengan adanya penelitian ini diharapkan agar dapat menginspirasi gerakan-gerakan kepedulian sosial baru di berbagai desa berupa gagasan dari masyarakat desa untuk dituai sebagai hasil kebermanfaatan bersama warga desa pula.

Kegiatan seperti ini diharapkan mampu terus berjalan dan tidak berhenti hanya sebatas dilakukan dikarenakan keadaan bencana seperti COVID-19 saat ini saja, agar setelah bencana ini hilang dan masyarakat perlahan pulih kembali, masyarakat justru mampu membawa kegiatan ini menjadi kegiatan kebermanfaatan yang lebih besar lagi bagi desa tersebut, salah satunya adalah ketercapaian kemandirian pangan desa yang lebih baik. Oleh karena itu penting melibatkan seluruh aktor yang ada, sebagaimana yang telah dijelaskan Valentina, Annissa, etal. (2020). Masyarakat seperti karang taruna dan warga desa lainnya dilibatkan dalam tahapan perencanaan, pelaksanaan, maupun 
evaluasi. Kemudian intensitas dialog antara pemerintah desa dengan masyarakat desa dapat dimaksimalkan kembali. Sebagaimana dapat diketahui bahwa keberhasilan kegiatan komunitas tidak dapat hanya diusahakan melalui pemerintah atau masyarakat saja, akan tetapi suatu kegiatan bersama yang hasilnya diharapkan terus berkontribusi dalam memberikan kemakmuran dan kesejahteraan bagi seluruh lapisan masyarakat. Perlu sinergitas antara peran pemerintah, baik aparat kelurahan dan instansi lain terkait. Lembaga swadaya masyarakat yang peduli ataupun perusahaan yang ada, kampus, dan terutama masyarakat desa itu sendiri.

\section{Kesimpulan}

Pembuatan Taman D'Terong yang dicetuskan sebagai gagasan dari masyarakat untuk kebermanfaatan bersama telah memperlihatkan bentuk kepedulian sosial masyarakat melalui gerakan ini sebagai resiliensi komunitas desa terhadap Pandemi COVID-19. Penelitian ini menggunakan metode studi kualitatif deskriptif melalui wawancara, observasi dan kepustakaan. Di mana hasil penelitian menunjukkan bahwa konsep resiliensi komunitas terhadap bencana memiliki efek percepatan pemulihan yang baik. Dengan kerangka kerja konsep melalui pendekatan berbasis modal terbukti bahwa modal-modal di dalamnya telah memperkuat resiliensi tersebut dari mulai modal sosial, modal ekonomi, modal sumber daya manusia, modal fisik, bahkan modal alam. Dimulai dengan inisiasi sepuluh warga yang pengangguran di tengah pandemi, kemudian mengajak warga untuk berswasembada tani.

Melalui pembiayaan pribadi warga, pemanfaatan lahan milik salah satu warga, serta bermodalkan ikatan yang kuat berupa kepercayaan, ke saling pengertian, dan nilai bersama, gerakan ini terus berjalan hingga mampu panen berkali-kali. Hasil panen dijual kepada warga sekitar dengan harga murah, di mana mampu meringankan beban belanja kebutuhan, dan menyumbang pemasukan kas desa untuk disalurkan ke warga membutuhkan serta pemutaran anggaran pengelolaan usaha tani. Dampak -dampak yang ditimbulkan dari gerakan pengelolaan Taman D'Terong telah mampu membantu percepatan pemulihan keadaan warga Desa Panggungharjo dengan memberikan lapangan pekerjaan baru, memberikan solusi atas pemenuhan kebutuhan pangan desa yang higienis dan terjangkau , memberikan pengalaman berwirausaha, mengembangkan hubungan keakraban satu sama lain, mengisi waktu luang, menyalurkan hobi, bahkan menjadi sarana rekreasi yang mampu menghilangkan kejenuhan akibat pembatasan berkala yang ditetapkan oleh pemerintah di tengah situasi krisis global saat ini.

Saran untuk pengembangan penelitian dalam bidang studi serupa yakni perlu dipahami bahwa konsep resiliensi komunitas terhadap bencana dengan pendekatan berbasis modal merupakan studi kajian yang masih terus berkembang dan masih memungkinkan untuk berubah, konsep ini pula masih belum digunakan untuk penerapan pada studi pembahasan yang lebih luas selain bidang bahaya dan kebencanaan sehingga terlalu stagnan di bidang dimensi itu saja, pengukuran yang ditentukan dalam penelitian ini masih terbatas dan memungkinkan untuk dikembangkan indikator-indikator pengukurannya untuk perkembangan ilmu pengetahuan yang lebih baik di masa depan. Saran juga ditujukan bagi pemerintah dalam memberikan pelatihan maupun bantuan dana yang diharapkan mampu mengembangkan desa tersebut, sebab keinginan mereka untuk menjadikan desa wisata sangatlah tinggi, akan tetapi kendala dana dan pengetahuan membuat mimpi tersebut di pendam untuk sementara waktu.

\section{Referensi}

Arieza, U. (2020). Mengukur Dampak Bila RI Terjerat Resesi Ekonomi Corona. CNN INDONESIA. https://www.cnnindonesia. com/ekonomi/ 20200624065542-532516736/mengukur-dampak-bila-ri-terjeratresesi-ekonomi-corona diakses pada 22 October 2020.

BPS. (2018). Proyeksi Penduduk Indonesia. Jakarta. https://www.bps.go.id/ publication/2018/10/19/7 8d24d90 20026a d95c6b5965/proyeksi- pendudukindonesia-2015-2045-hasil-supas-2015. html diakses pada 22 October 2020.

Cahyono, B., Ardian, A. (2020) . Peran Modal Sosial Dalam Peningkatan Kesejahteraan Masyarakat Petani Tembakau Di Kabupaten Wonosobo. Jurnal CBAM-FE UNISSULA 1 (1), pp.131-144. 
Roichan Rochmadi Irwanto, Tuti Rokmawati, Ratu Hanifa Pradnya Siwi - Inisiasi Taman D'terong sebagai

Dianawanti, V. (2020). Riset Tunjukkan Gaya Hidup Orang Indonesia Berubah Karena Virus Corona COVID-19." Liputan 6. https://www.liputan6.com/ bola/read/4225707/riset-tunjukkan-gayahidup-orang-indonesia-berubah-karenavirus-corona-COVID-19).

Gugus Tugas Percepatan Penanganan COVID-19. (2020). Laporan Pasien Positif COVID-19. Jakarta.

Husaini, U., Akbar, P. S. (1996). Metodologi Penelitian Sosial. Jakarta: Bumi Aksara.

Indayani, S., Hartono, B. (2020). Analisis Pengangguran dan Pertumbuhan Ekonomi sebagai Akibat Pandemi COVID-19. Jurnal Perspektif: Jurnal Ekonomi \& Manajemen Universitas Bina Sarana Informatika, 18(2),pp. 201-208. doi: doi.org/ 10.31294/jp.v17i2

Kementerian Kesehatan RI. (2020).Pedoman Pencegahan dan Pengendalian CORONAVIRUS DISEASE (COVID-19) Revisi ke-5. Jakarta. https://covid19.go.id/p/protokol/ pedoman-pencegahan-dan-pengendaliancoronavirus-disease-covid-19-revisi-ke-5

Lexy, J. M. (2005). Metodologi Penelitian Kualitatif. Bandung: Remaja Rosdakarya.

Marshall, N., Fenton,D.M., Marshall, P.A., Sutton, S. (2007).How Resource-Dependency Can Infl uence Social Resil ience Within a Primary Resource Industry. Rural Sociology 72, pp. 359-390.

Mayuga,J.S. (2007). Understanding and Applying the Concept of Community Disaster Resilience: A Capital-Based Approach. (Working Paper Prepared for The Summer Academy, Megacities as Hotspots of Risk: Social Vulnerability and Resilience Building, Munich, Germany, 22-28 July 2007).

Moko, M. (2020). Terungkap! Indonesia Resesi Sejak Kuartal I. SuaraMerdeka.Com.
Ruth, M. (2020). Berbagai Negara Mulai Longgarkan Lockdown Dan Pembatasan Sosial , Https://Katadata.Co.Id/ Marthathertina/Berita/5eaff146d3245/ Berbagai.

Sudirah, S., Susanto, A., Sumartono, S., Syukue, M. (2020). Hubungan Penguatan Modal Sosial, Mitigasi Bencana Banjir dan Peningkatan Produksi Pertanian. Equilibrium Jurnal Pendidikan, 8(1), pp.75-84. doi: doi.org/10.26618/ equilibrium.v8i1.3094

Timmerman, P. (1981). Vulnerability, resilience and the collapse of society: A review of models and possible climatic applications. Toronto: Institute for Environmental Studies, University of Toronto.

Valentina, A., Wardany, K., Mariana,E . (2020). Partisipasi Masyarakat Nelayan dalam Pemberdayaan Ekonomi di Desa Margasari, Kecamatan Labuhan Maringgai, Lampung Timur. Jurnal Masyarakat Maritim, 4 (1), pp.1-11. https://doi.org/10.31629/jmm.v4i1.2566 Wahyudi, A., Ritohardoyo, S., \& Pitoyo, A. J. (2020). Resiliensi Masyarakat Penghuni Sempadan Sungai Madiun Dalam Menghadapi Banjir. Majalah Ilmiah Dan Informasi Kegeografian, 18(2), pp. 1-9. doi: doi.org/ https:/ / doi.org/ 10.21831/ gm.v18i2.32339

Yuniar, R. W. (2020). Resesi ekonomi Indonesia: Pemerintah disarankan fokus 'menangani pandemi' demi perbaikan ekonomi." $\quad B B C \quad$ News Indonesia. https:// www.bbc.com/ indonesia/ indonesi a-53152994 